\title{
DEVELOPMENT STRATEGY OF MATALAFANG TRADITIONAL VILLAGE AS A CULTURAL TOURISM DESTINATION
}

\author{
Yudha Eka Nugraha ${ }^{(1) *}$, Emy Chlarita Lema ${ }^{(2)}$ \\ (1)(2) Politeknik Negeri Kupang \\ yudhaekanugraha@gmail.com , chazelyaemy@gmail.com \\ Submitted:8 January $2021 \quad$ Revised: 12 March 2021 \\ Accepted : 21 March 2021
}

\begin{abstract}
This study aims to describe the tourism potential and formulate the development of the Matalafang Traditional Village as a cultural tourism destination in Alor Regency. Matalafang Traditional Village is one of the tourist destinations, where the Abui tribes live. The Abui tribe, as one of the largest tribes who inhabit Nusa Kenari Island, has various cultural potentials tourism to be developed. This is in line with the increasing number of tourists visiting. Through qualitative descriptive methods, extracting information is obtained by field observations, structured interviews with six key informants, documentation of traditional villages, and literature studies on Matalafang Traditional Village and Alor Regency Tourism. The results showed that the attractiveness of cultural tourism in the Matalafang Traditional Village in the form of the Balai Hatel Traditional Ceremony as a ritual to enter the garden, the Caka Lele dance, the unifying dance of the Alor community Lego-Lego, weaving Ikat for dancing, the fourth level traditional house, and various woven bamboo crafts for putting sirih pinang traditional snacks on it. The strategy formulation is an effort to develop the Matalafang Traditional Village as a cultural tourism destination, such as increasing the awareness of culture-based tourism for the local community, maintaining the authenticity of dance as a tourist attraction, increasing tourist activities after the ritual of opening the garden as alternative tourism, and maintaining the condition of the traditional village that is still original.
\end{abstract}

Keywords: Destinations, Traditional Villages, Matalafang, Cultural Tourism, Development Strategies

\section{INTRODUCTION}

Alor Regency in East Nusa Tenggara Province is well known as several names such as Nusa Kenari Island and Seribu Moko Island. Sometimes some people call it "Taramiti Tominuku" as a unifying motto for the people of Alor. Alor Regency has a variety of regional languages that distinguish each tribe that inhabits it (Anggayana et al, 2020), (Asa \& Santosa, 2020). The uniqueness in the naming is comparable to the potential for cultural tourism in Seribu Moko Island.

The richness of this cultural potential is fully managed by the cooperation of various parties, namely the Alor District Government (Muawanah et al, 2020), the private sector that provides supporting facilities such as accommodation, transportation (Tjahjono et al, 2019), and local communities participation as an important element in tourism management (Gorang, 2018). 
The number of marine tourism potentials that Seribu Moko Island (Tokan, 2015) should make Seribu Moko Island get a lot of tourist visits and become superior in the tourism sector (Darsiharjo, 2016). One of the tourist attractions in Alor Regency which starts to be visited by many tourists is the Matalafang Traditional Village. Matalafang Traditional Village is one of the destinations in Alor Regency which is unique in the form of a Traditional Village located in West Lembur Village, Alor Tengah Utara District, Alor Regency. This village can be accessed by tourists because of its premium access in supporting destinations. The time it takes to get to the Matalafang Traditional Village is 25 minutes from the center of Kalabahi City (the capital of Alor Regency). The people who inhabit the Matalafang Traditional Village are the original inhabitants of the Abui Tribe, where the Abui Tribe is one of the largest tribes who are domiciled on Alor Island, East Nusa Tenggara (Alelang et al, 2018).
Traditional village communities have a cultural potential, one of which is to respect the environment by making a customary ritual of opening land known to the people of the Matalafang Traditional Village called Balai Hatel. In addition to the land clearing ritual, the Abui people in the Matalafang Traditional Village similar to the celebration of life which is manifested in a combination of movement and music as a representation of the daily life of the people who rejoice in all conditions. This activity is called by the community with the Lego-lego Dance as an attraction that is often presented to tourists who come. Before being commercialized as a tourist activity, this dance was a dance of the Alor community. Various unique and interesting cultural tourism potentials in the Matalafang Traditional Village often get tourist visits. Tourist visits obtained in this study are tourist visit data since 2017 as follows:

\section{Table 1. Tourist Visit Data in Matalafang Traditional Village}

\begin{tabular}{lll}
\hline No & Years & Visitor \\
\hline $\mathbf{1}$ & 2017 & 1890 \\
\hline $\mathbf{2}$ & 2018 & 1000 \\
\hline $\mathbf{3}$ & 2019 & 2050 \\
\hline & (Source: Matalafang & Traditional Village Data, 2020)
\end{tabular}

Based on the explanation in the table above, the number of tourist visits in the Matalafang Traditional Village during the last three years shows various fluctuations in visits. However, the trend of tourist visits continues to increase, up to 2050 tourists per year in 2019 or around 170 tourists per month coming to do cultural tourism in the Matalafang Traditional Village. The increase in tourist visits occurred due to various efforts by the central and regional governments that are actively promoting tourism in Indonesia and access to transportation that is getting easier and cheaper. Unfortunately, after the observation was made it was found that the local people did not have a good tourism education. Every tourist visit that comes, the village community does not participate much. Even some of the guests were escorted by travel agents and accompanied by people who were not local people. Even though this potential is an advantage for the local community to actively participate in tourism activities.

Research on Traditional Villages has been carried out before by (Kusi, 2020) and (Osin, 2019) in previous research that traditional villages have cultural wealth and development funds are carried out by maintaining cultural authenticity. More than that, this research not only formulates a development strategy, but also describes the various tourism potentials along with 
the tourism components of the Matalafang Traditional Village. There have not been many studies on customary villages, so this research seeks to add treasures to culturebased tourism.

High community participation in the management of traditional villages is a gift for local communities that can be optimized. Therefore the community must participate actively, not only for the benefit of regional income. More than that, efforts are made to strive for the potential of traditional villages to lead to the preservation of regional culture. Various parties including the local government have made efforts to manage and market tourism products therefore there is regional income. However, the community as managers needs to be given various stimuli for the development of insights in order to manage tourist attractions in accordance with existing cultural potentials. In developing cultural tourism, it is necessary to implement the development of the $4 \mathrm{~A}$ tourism component (Suwena, 2010).

Matalafang Traditional Village has a lot of potential and cultural uniqueness that can be developed into assets and can also attract tourists, but lack of human resources (HR), lack of supporting facilities, lack of community creativity in providing culture-based souvenirs, access roads to locations that are lacking.

The lack of the community's role in promoting the Matalafang Traditional Village as well as the lack of awareness of the local community and knowledge of the role and efforts to develop tourism potential in the Matalafang Traditional Village can be seen from the habits of the community where when there is a visit of foreign tourists the community tends to be passive and become spectators.

This study seeks to describe the potential and formulate a strategic direction for the development of the Matalafang Traditional Village as a cultural destination.

\section{LITERATURE REVIEW Tourism Development}

Some of the definitions regarding tourism development in this research, namely; according to (Arjana, 2016: 125) tourism development must focus on developing tourist attractions, both natural tourism, cultural tourism, artificial tourism, and alternative tourism. The needs of tourists in terms of natural beauty, the need to watch cultural performances, buy art products as souvenirs must be planned in tourism to meet the needs of tourists. (Mulyadi, 2012: 89) also states that tourist destinations must have a unique attraction to bring in tourists with three important aspects, namely; attractions, accessibility, amenities, and additional services.

Culture-based traditional village development strategies have been studied before by (Kusi, 2020) and (Osin, 2019). Based on this research, the development of traditional village tourism must emphasize the preservation of culture therefore it is always original. This research is relevant considering that the location of the research is in East Nusa Tenggara Province therefore there are similarities in the characteristics of the community. However, this research is specifically carried out in Alor and presents practical strategies for developing culture-based traditional village tourism by maximizing community participation and cultural authenticity.

\section{Cultural Tourism}

Cultural tourism is a field in tourism that is starting to get attention, especially by the government. Research according to (Nafila, 2013) states that cultural tourism is a type of tourism that makes cultural attractions the main attraction. In this type of tourism, tourists will be guided to enjoy experiences related to culture, namely understanding local cultural elements, local wisdom in tourist destinations, studying historical places, studying museums, studying the 
representation of values and living systems adopted by local communities, performing arts, and culinary specialties from the local community.

According to (Jovicic, 2016) aspects included in the attraction of cultural tourism include; birth ceremonies, various traditional dances, musical instruments and traditional music performances, wedding ceremonies, traditional clothes, various kinds of ceremonies and rituals, historical buildings, cultural heritage, traditional relics, traditional fabrics (for example woven fabrics), cultural festival exhibitions, and other traditional performances, textile products, historical museums, culture, as well as other local customs that have not been mentioned. According to Koentjaraningrat (2004), cultural elements consist of seven elements, including; language, knowledge systems, social systems or social organizations, tools of life and technology, livelihood systems, religious systems, and arts.

\section{RESEARCH METHOD}

This study used a qualitative descriptive method (Sugiyono, 2015). The data collected is divided into two types, namely qualitative data in the form of results from interviews with key informants. Quantitative data collected as secondary data regarding the number of tourist visits. The primary data obtained were then collected using observation techniques in the Matalafang Traditional Village, documentation of each research process, and structured interviews with informants, while secondary data was collected through tourism books from the relevant district government. A total of six informants were the key informants in the study which were selected based on the type of non-probability purposive sampling based on certain criteria, namely; is a tourist actor in Alor Regency, knows various information needed in research on the development of the Matalafang Traditional Village and the manager of the traditional village. Based on these criteria, key informants are obtained, namely the Head of the Service, Head of the Destination Division of the Tourism Office of the District. Alor, Head of West Lembur Village, Manager of Matalafang Traditional Village, Local community of Matalafang Traditional Village, and Tourists. The data that was collected were analyzed using field data reduction techniques, data presentation, SWOT analysis (Kotler, 2002), and drawing conclusions. Furthermore, the variables in the SWOT analysis are the strength of the tourism system, the weakness of the tourism system, the opportunities for the tourism system, and the threat of the tourism system in the Matalafang Traditional Village.

\section{RESULTS AND DISCUSSION Overview of the Matalafang Traditional Village}

The Matalafang Traditional Village is a traditional village located at the foot of the mountain and surrounded by small hills and is a coastal area. The location is in RT 005, RW 003, Lembur Barat Village, Alor Tengah Utara District, Alor Regency, East Nusa Tenggara Province. As a traditional village, this place has seven traditional houses in the form of stilt houses in the form of pyramids with thatch roofs which are neatly arranged and uniquely along the Matalafang Traditional Village.

The word Matalafang itself in the Abui language is defined as seeing eyes just cut off. The people who inhabit this village come from the Abui Tribe where the Abui Tribe is the largest tribe that inhabits the island of Alor. The Abui tribe is usually nicknamed the Big Mountain because there are many high hills that surround villages or residential areas. The matalafang traditional village was founded in 1942, initially there were only dozens of residents living in the Matalafang 
Traditional Village. But over time the number of Abui descendants grew although the offspring are now starting to spread. Until now, there are thousands of people. Most of the people of West Lembur Village are spread from this traditional village. The daily life of the Abui people in the Matalafang Traditional Village is to work to utilize natural products, especially in the forest, for gardening, and hunting. Even though the area is located on the coast, none of the residents who live in the Matalafang Traditional Village live from utilizing marine products or working as fishermen. During the day, the atmosphere of the traditional village is quiet because most of them go to the forest to hunt and find food. Some of the proceeds from hunting are consumed to meet daily needs and some are sold to the market to meet other needs such as school children and household needs. The original food of the Abui Tribe and the Alor people in general is corn (catemak) and tubers, rice is also consumed but is still interspersed with corn and sweet potatoes.

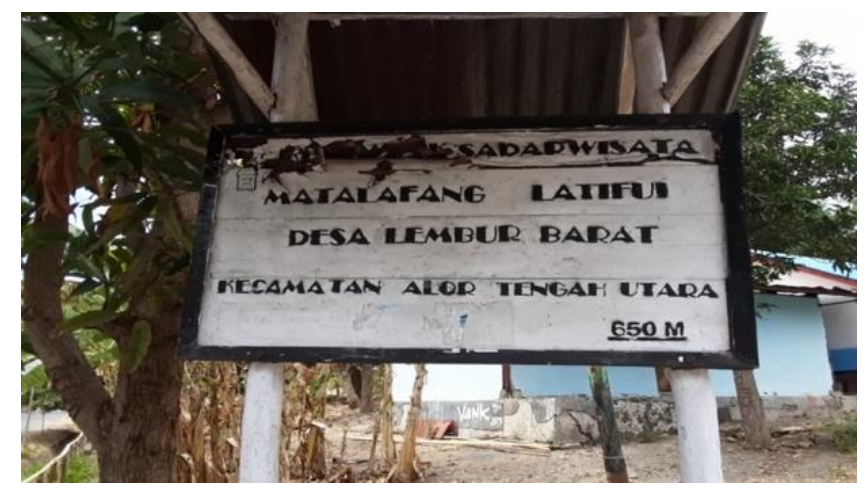

Pic 1. Matalafang Traditional Village Nameplate

Source: Research documentation, 2020

In addition, the Matalafang traditional village has one unique tradition, namely the Balai Hatel ritual or commonly known as cutting the garden or opening new land which is carried out on July 28 every year. This ritual is performed by the chief of the tribe and presented by the local community and government to witness it. The traditional house of the Abui tribe in the Matalafang Traditional Village is simple but alluring. This traditional house is usually called a warehouse. The building is made of wood and bamboo. Matalafang Traditional Village has two types of traditional houses, namely Katilang (crown) and Sometime (without crown).

The house called Katilang is a traditional house that is only inhabited or the only ones who enter into it are the tribal chief or eldest son of the tribe. If there are other people who want to enter, they must have the permission of the chief or eldest son of the tribe, while the house that is "disbeut" is sometimes a house usually inhabited by the local people of the Matalafang Traditional Village. Even though it has a different name, the shape of this traditional house is actually the same which distinguishes the two traditional houses is the crown which is located at the end of the roof of the traditional house.

This traditional house is in the form of a house on stilts and in the form of a pyramid with a thatched roof with four support poles and has four levels with different functions. The 1 st floor is a place to rest or receive guests, the 2 nd floor is used for cooking and sleeping at night, the 3rd floor is for storing food, and the 4th floor is for storing heirlooms or belongings. Even though the building is made of wood and bamboo, this traditional 
house can last for decades. Matalafang Traditional Village has seven traditional houses, one is a traditional house and six others are ordinary houses, while there are five houses using walls.

\section{Matalafang Community Profile}

The Matalafang Traditional Village is a traditional village located at the foot of the mountain and surrounded by small hills and is a coastal area. The location is in RT 005, RW 003, Lembur Barat Village, Alor Tengah Utara District, Alor Regency, East Nusa Tenggara Province. The Matalafang Traditional Village was established in 1942, as a tourist destination by the Government of the Alor Regency Tourism Office on July 28, 2002. Matalafang Traditional Village is the third oldest traditional village in Alor Regency after the Takpala Traditional Village and the Monbang Tribe Traditional Village. The Matalafang Traditional Village has an area of about six hectares with a population of 30 people from seven families.

This Matalafang Traditional Village was originally located on a hill called Matalafang which then in 2004 Alor experienced an earthquake therefore this village was moved down to a small mosque called Latifui. There is a compelling reason for the relocation of this traditional village because there is a story that in ancient times people celebrated traditional parties and their ancestors or ancestors from this Latifui traditional village chanted between Lego-lego circles and only one person could chant therefore after chanting in the village of Matalafang the singer ran again and moved to Latifui to chant there. This is the reason why Matalafang Traditional Village was moved to Latifui Village. Even though it has been moved, the name of this traditional village is still Matalafang because it has been legalized by the government.

The Matalafang Traditional Village is located at the foot of the mountain and is a coastal area. Even though the area is located on the coast, none of the residents who live in the village live by marine products or fishermen but the residents use forest products as a source of life, where all Matalafang people work as farmers. In addition to using the forest as plantation land, the Matalafang community also uses the forest as a place to hunt animals. The Matalafang community has two traditional houses inherited from their ancestors, namely Katilang and Sometimes. Katilang means crown and Sometimes means without crown. This traditional house is the pride of the Matalafang community because it is quite well organized and has a unique shape because it has four levels.

This traditional house was made without using modern materials, namely wood, bamboo, reeds, and rattan rope to tie. Even though, the Matalafang community maintains and carries out the traditions that have been passed on by their ancestors, the Matalafang people are also people who fear God. Where the majority of Matalafang people believe in Protestant Christianity. The hospitality of the community and village life is an attraction and attraction for tourists. Even though they did not receive higher education, the entire Matalafang community was very fluent in Indonesian therefore it did not make it difficult for tourists to communicate while visiting.

\section{Tourism Potential Attractions of Matalafang Traditional Village}

The Matalafang Traditional Village is one of the traditional villages that was only famous a few years ago even though its existence has existed since long ago in Lembur Barat Village, Alor Regency. The Matalafang Traditional Village was used as a tourist destination by the Government of the Alor Regency Tourism Office on July 28, 2002. This is inseparable from the tourism potential of the Matalafang Traditional Village so it is worth visiting.

The Matalafang Traditional Village has tourism potential that should be 
maintained and preserved. Tourism potential, especially cultural tourism potential, are as follows:

1) Traditional ceremonies or traditional rituals that are still maintained (Traditional rituals of Balai Hatel or entering the garden).

This ritual is carried out by burning a bunch of raw peeled bananas then the chief standing on the altar holding the raw banana peel and the bunch, then the chieftain uses ancient poetry asking for blessings and instructions from the Creator. After the tribal chief mentions the names of the places that will be used for

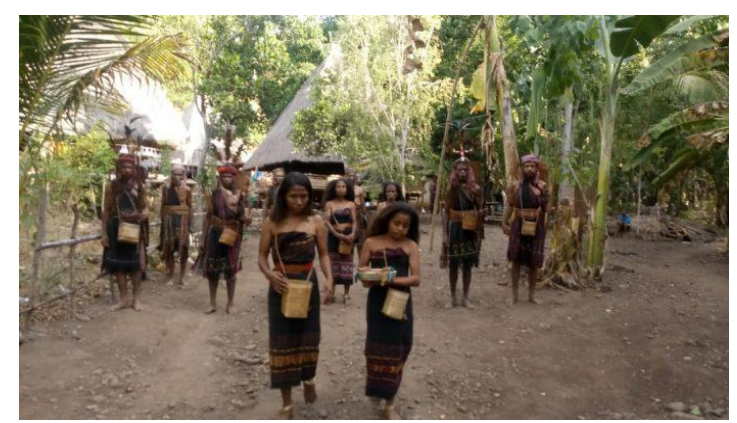

(2) planting and the tribal chief shakes the bananas, if the bananas are released from the bunches by a lot then the name of the place mentioned will produce a lot of garden yields but if only a few bananas fall, the crop a little. This was done over and over again until all the names of the places that were to be used for planting were mentioned. Then they will make circles and Lego-lego around the altar as a form of gratitude to the creator. After this traditional ritual procession is carried out then the community is allowed to enter the garden.

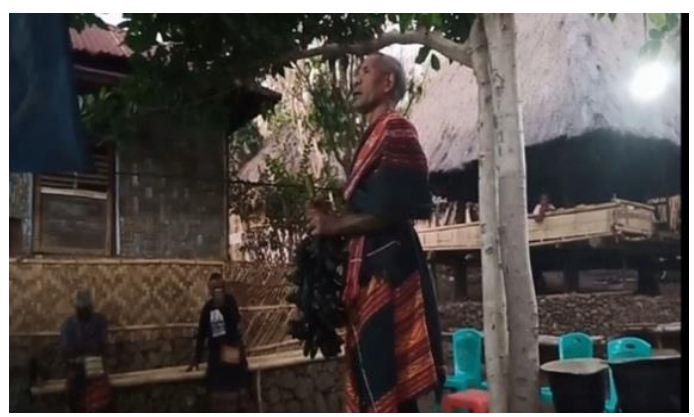

(3)

Pic (2). Welcoming Ritual Guests Balai Hatel, (3) Traditional rituals of the Balai Hatel tribe by the head of the tribe

Source: Research documentation, 2020

According to the Chairman of the Matalafang Village Custom, Mr. Karel Malbieti, this ritual is one of the cultural attractions that is always a spectacle for both domestic and foreign tourists. With the simplicity of the ceremony, local people feel proud because they can display a culture that can be enjoyed by tourists. Both tourists and local governments take part in ritual activities to leave a memorable impression, stories that can be brought home when visitors return to their places of origin.

\section{1) Has a special dance, namely the caka catfish and lego-lego dances.}

The Abui tribe, which is known as the largest tribe in Alor Regency, has a distinctive dance, namely The Caka Lele and Lego-lego dances. These two dances have also become the typical dances of
Alor Regency. The Caka Catfish dance is a war dance dedicated to the king. This dance is played when going to war and finish fighting. The Caka Catfish dance is usually played by two men who swing each other's kalewang (sword) while following the rhythm of the drum and gong being played.

Meanwhile, the Lego-Lego dance is a united dance for the Alor people, especially the Abui Tribe. Abui people call this Lego-lego dance Taramiti Tominuku or the Indonesian language is different but we are still one. The meaning of this sentence is to let us be different from our hometowns, but we are one in the Legolego circle, in this circle we are all one who symbolizes the prostration of gratitude to the ancestors. The Lego-lego dance is usually played by at least 20 
people, this dance is usually played in large numbers and is played by men and women while singing and replying to rhymes accompanied by the sound of drums and gongs. Tambur and gong are musical instruments for the Alor people.

The local community preserves these two dances with monitoring carried out by a tourism awareness group in the Matalafang Traditional Village. Through

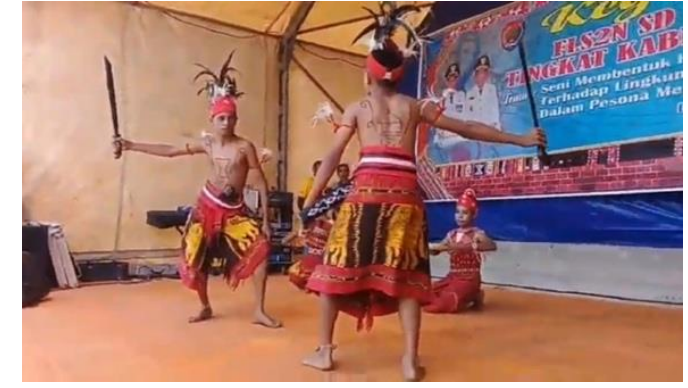

(4) various programs, namely training kindergarten to high school children in Alor to be able to perform the Caka Catfish and Lego-lego dances. This effort is a regeneration therefore the young generation in Alor will continue to practice the richness of Alor culture as an attraction, especially in the Matalafang Traditional Village.

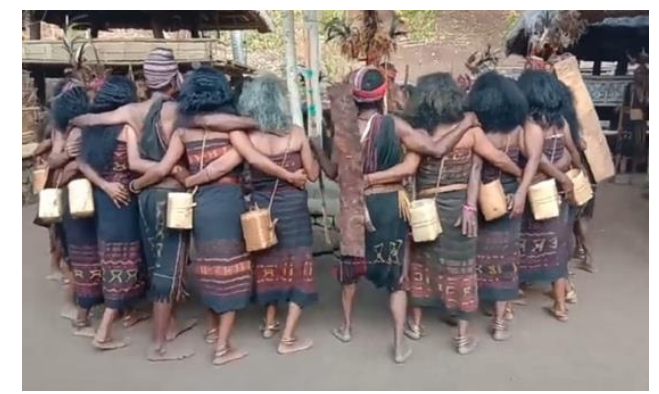

(5)

Pic. (4) Caka Lele Dance, (5) Lego-lego dance by the Matalafang community Source:

Research documentation, 2020

\section{2) Traditional four-storey house}

Matalafang has seven traditional houses, this house is in the shape of stilts and in the form of a pyramid with thatched roof with four support poles and has four levels with different functions. The 1 st floor is a place to rest or receive guests, the 2nd floor is used for cooking and sleeping at night, the 3rd floor is for storing food, and the 4th floor is for storing heirlooms or belongings. Even though the building is made of wood and bamboo, this traditional house can last for decades. Tourists have a high interest in this traditional house. Usually, tourists prefer to stay on top of this house rather than sleeping in the homestay provided. Local people still use this place as a place to rest, a place to store food, and a place to remember their ancestors.

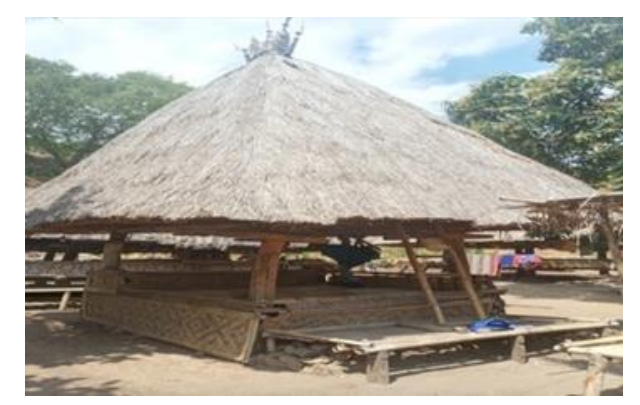

Pic 6. Four-storey traditional house

Source: Research documentation, 2020

\begin{tabular}{llrr} 
Matalafang & \multicolumn{2}{c}{ Traditional } & Village \\
Development & Strategy as a & Cultural \\
Tourism Destination & Using & SWOT \\
Analysis & & &
\end{tabular}

Internal Strengths and Weaknesses

This study used descriptive analysis and then further analyzed with the SWOT 
approach (strength, weakness, opportunity, and threat) which was used to plan the development of the Matalafang Traditional Village as a cultural tourism destination. The SWOT analysis is intended to find out an overview of the strengths and weaknesses of the development of cultural tourism in the Matalafang Traditional Village as well as the opportunities and threats it faces. The potential for dominant cultural tourism makes Matalafang Traditional Village has five strengths and three weaknesses which were identified during observations and interviews in the field. The strengths and weaknesses of the Matalafang Traditional Village are:

\section{a. Strength}

1. The Matalafang Traditional Village has an original and unique cultural tourist attraction.

The Matalafang Traditional Village is one of the traditional villages that is not very well known when compared to the Takpala Traditional Village. However, this destination has unique and interesting tourism potential to visit. The potential for cultural tourism in the Matalafang Traditional Village has an authenticity and cultural enhancement that is still maintained today such as the Traditional Ritual of opening new land (Balai Hatel), the Caka Lele dance and Lego-lego as a unifying dance for the Alor community and a traditional four-storey house.

2. The destination has a tourism awareness group that is active in preserving the dance culture of the Matalafang Traditional Village

The Matalafang Traditional Village is a traditional village located at the foot of the mountain and surrounded by small hills and is a coastal area. When viewed from the hill, which is still behind the Matalafang traditional village, the natural charm of the Matalafang traditional village looks neat. To maintain this uniqueness, the traditional leader formed a tourism awareness group for the Matalafang Traditional Village whose main task was to carry out cultural preservation. Examples of cultural preservation efforts that have been carried out by the Matalafang Traditional Village tourism awareness group are dance competitions and training in traditional Caka catfish and Lego-lego dance for kindergarten to high school children on Alor Island. This is a step to preserve the dance therefore it will continue into the future.

3. Local people are very friendly to visiting tourists

The Matalafang community is a friendly community with visitors who come to their place. Their hospitality is shown through welcoming the local community to every visiting tourist by giving a sincere smile as a sign of welcome and continued by giving betel nut and coffee, this is not required for tourists but they still do it because it is a habit of the Abui people who have been practiced by generations. Hereditary. The habit of serving betel nut and coffee is part of a cultural element related to a social system that has been carried out from generation to generation. The community is able to use good Indonesian therefore this supports the hospitality that occurs between visitors and the owner of the Matalafang Traditional Village area.

4. The tourist destination has a variety of local handicrafts as amenities for the Matalafang Traditional Village

The people of the Matalafang Traditional Village are a creative society. This has become a habit from generation to generation. The limited tools and resources that can be used have made people adapt to the situation. Tools commonly used as body armor, such as weaving, tools for carrying betel nuts such as woven bamboo, are commodities that can be sold, and served as souvenirs for visiting tourists. The community has so far received training on how to come up with unique 
ideas for creating artificial handicrafts using natural materials. Forms of crafts of the Matalafang community such as making necklaces, bracelets, betel nuts, belts, cups, baskets, weaving, and so on, which is one of the attractions of the Matalafang Traditional Village.

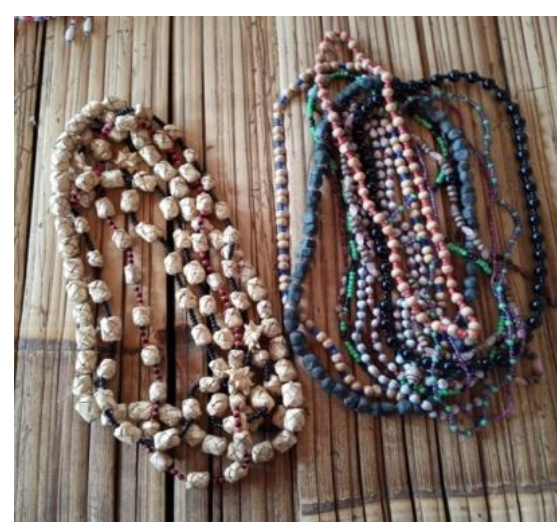

(7)

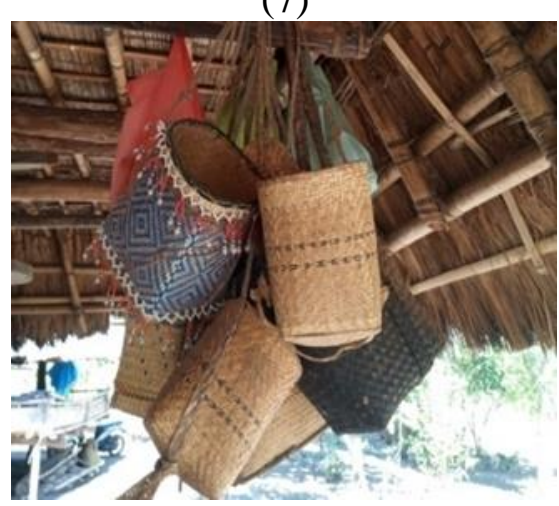

(9)

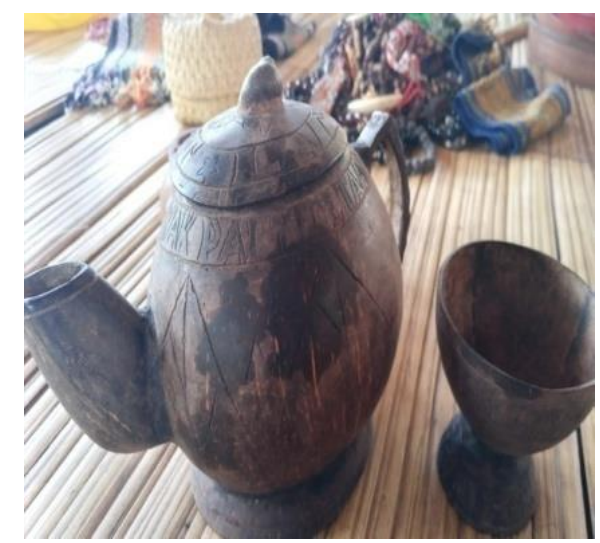

(8)

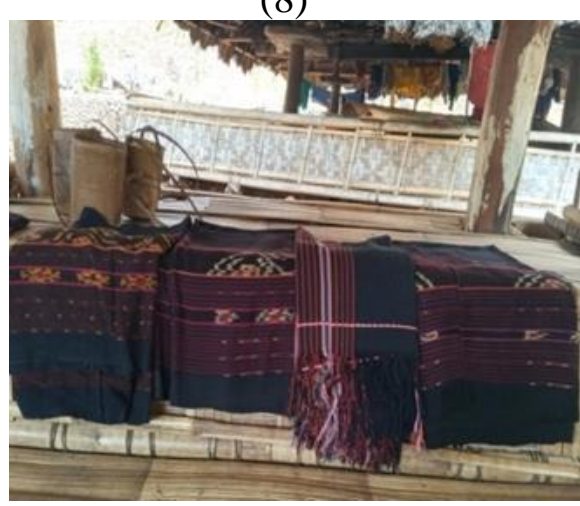

(10)

Pic (7) Necklaces and bracelets made of natural products, (8) Kettles and cups made from coconut shells, (9) woven bamboo bags (10) woven originally from the Abui tribe, Source: Research documentation, 2020

5. The distance between the city center and tourist destinations can be reached quickly in less than 30 minutes

The Matalafang Traditional Village is one of the newly developed traditional villages because it is the closest to the city center of Kalabahi. This destination is easiest to reach by using public transportation, private two and four wheels. Even though the road is a little rocky, the access is still accessible by tourists.

\section{b. Weakness}

Apart from having the strength as potential, the Matalafang Traditional Village also has weaknesses like this.

1. The weak quality of human resources makes service to guests less than optimal The people of Matalafang Traditional Village are generally not aware of tourism. During this research, the tourism actors in the Matalafang Traditional Village were only the same actors. The community has not actively participated, for example by providing food and drinks, serving as local tour guides, and renting a weaving or 
toilet. The community has not prioritized tourism as their main field, and has chosen to be spectators only. Lack of knowledge on how to develop existing tourism potential and foreign languages makes it difficult for people to get foreign tourist visits.

The community has not seen economic benefits as the main thing in tourism activities, thus, there is no entry ticket required to enter the Matalafang Traditional Village and the use of traditional clothing is also given free of charge to visitors. The income is only obtained from Lego-lego dance performances, staying at homestays, and also selling food and drinks which are only managed by traditional house owners.

2. Lack of facilities and infrastructure to support tourism activities

The facilities certainly support all tourism activities in the Matalafang Traditional Village. Even though there is a simple parking area, homestay, toilets, and various supporting facilities that already exist, the condition of the Matalafang Traditional Village still lacks many facilities. The existing homestays are still very simple, so they need renovations to make them more feasible, information boards, and trash cans are the most basic things that should already be in a tourism destination. The community also needs assistance in providing a place to sell merchandise, such as weaving stalls and food and beverage stalls. The reason why the community does not participate in providing tourism support facilities is because of the limited economy.

3. At some points the road access is rocky and not good

Roads are a very important part of infrastructure to support tourism activities, however, road access from the main road to this traditional village is still not good. The Matalafang Traditional Village which is being developed has begun to receive an increase in tourist visits. However, even though for the last three years it has received tourist visits. Road access never gets attention so tourists who come must be extra intent. Sometimes the road is rocky and several points of the way uphill make the trip less enjoyable even though the destination to be visited is of high cultural

\section{Tabel 2. IFAS (Strengths and Weaknesses of Matalafang Traditional Village)}

\begin{tabular}{|c|c|c|c|c|}
\hline No & Strengths & Skor & Bobot & Total \\
\hline 1 & $\begin{array}{l}\text { Matalafang Traditional Village has an original and unique } \\
\text { cultural tourist attraction }\end{array}$ & 4 & 0.140 & 0.561 \\
\hline 2 & $\begin{array}{l}\text { The destination has a tourism awareness group that is active in } \\
\text { preserving the dance culture of the Matalafang Traditional } \\
\text { Village }\end{array}$ & 3 & 0.123 & 0.368 \\
\hline 3 & Local people are very friendly to visiting tourists & 4 & 0.193 & 0.771 \\
\hline 4 & $\begin{array}{l}\text { This tourist destination has a variety of local handicrafts as } \\
\text { amenities for the Matalafang Traditional Village }\end{array}$ & 4 & 0.158 & 0.631 \\
\hline 5 & $\begin{array}{l}\text { The distance between the city center and tourist destinations } \\
\text { can be reached quickly in less than } 30 \text { minutes }\end{array}$ & 3 & 0.105 & 0.315 \\
\hline No & Weakness & Skor & Bobot & Total \\
\hline 1 & $\begin{array}{l}\text { The weak quality of human resources makes service to guests } \\
\text { less than optimal }\end{array}$ & 3 & 0.105 & 0.315 \\
\hline 2 & $\begin{array}{l}\text { Lack of facilities and infrastructure to support tourism } \\
\text { activities }\end{array}$ & 2 & 0.088 & 0.175 \\
\hline \multirow[t]{2}{*}{3} & At some points the road access is rocky and not good & 2 & 0.088 & 0.175 \\
\hline & TOTAL & & 1.000 & 3.315 \\
\hline
\end{tabular}

(Source: Processed Research, 2020) 
Table 2 is the IFAS processed results obtained from the six key informants of this study. Data from interviews are quantified based on the results of interviews with informants. The total IFAS score obtained is 3.3158 which is in quadrant I which is strong (3.3).

4. External Factors Opportunities and Threats

Furthermore, in the analysis of external factors, this study identifies three opportunities and two threats which are priority problems that must be resolved by local communities and local governments. The external factor is the substance that is outside the destination but has a strong influence in the development of the Matalafang Traditional Village. The following is a list of opportunities and threats identified;

\section{a. Opportunities}

1. A massive promotion of Alor tourism by the Central and Local Governments

The NTT Provincial Government has made tourism one of its leading work programs. Through the theme Ring of Beauty NTT, New Tourism Territory, and various activities that support the development of tourism activities in NTT. The central government has also set one of the destinations in NTT, namely Labuan Bajo, as a super premium destination. This determination not only makes Labuan Bajo a leading destination, but also the surrounding islands to be interesting to visit, one of which is Alor with Matalafang Traditional Village as its superior destination. The existence of the Matalafang Traditional Village as one of the attractions of cultural tourism that offers tours of authenticity of dances, traditional rituals, ceremonies, and the sensation of traditional experiences that do not exist anywhere else shows that the development of cultural tourism destinations has a large market opportunity. It can be seen from the number of visits that tend to increase.

2. The interest of the local community, namely the young generation, is high to preserve the traditional Alor dance

Through a tourism awareness group formed for the Matalafang Traditional Village. Communities with limited knowledge and resources try to keep preserving culture as a top priority. The implementation of the Caka lele and Legolego dance competitions for the younger generation that has been carried out shows that the people of Alor also positively accept these activities. Participants who take part in this traditional dance competition are required at each educational institution therefore traditional dances will be maintained.

3. Local people who begin to understand the use of technology and information

The number of young people who are now starting to become dominant is very close to the use of technology and information. Therefore, with the advancement of technology and information, it is easier for the community to promote and sell packages through various media to introduce the uniqueness and beauty of the Matalafang Traditional Village. Only the lack of education on how to make packages and create content that will attract the attention of the wider community is one of the obstacles that must be resolved immediately by the authorities in the Matalafang Traditional Village. The existence of cooperation between the management and the government, private parties or social institutions engaged in tourism can guide and direct the development of the Matalafang Traditional Village to be more ready and to complement existing deficiencies therefore it can provide progress for the Matalafang Traditional Village. 


\section{b. Threats}

1. Tourism for the community is still underestimated, not many have fully participated in tourism activities

Tourism is something new for the people of the Matalafang Traditional Village. Unlike the two previous traditional villages that are familiar with tourism. Matalafang Traditional Village needs further education about tourism awareness and its impact on social welfare. People still prioritize themselves as hunters to fulfill their daily needs. Meanwhile, mothers and children watch tourism activities and always look foreign to the tourists who come, especially foreign tourists. The local community can actually continue to carry out their main duties as hunters and farmers in the forest. However, what's wrong with trying tourism activities as additional income for families that will improve social welfare and the quality of life of the people in Matalafang Traditional Village.

2. Competition with the two formerly famous traditional villages

The Matalafang Traditional Village stands between two traditional villages that were already known earlier, namely the Takpala Traditional Village and the Bang Towo Traditional Village, where these three traditional villages offer cultural tourism. Facing this, the Matalafang traditional village must have its own characteristics that differentiate between the existing traditional villages. This has not been identified by existing stakeholders therefore it becomes a threat to the development of tourism in Alor Regency.

Tabel 3. EFAS Opportunities and Threats of the Matalafang Traditional Village

\begin{tabular}{lllll}
\hline $\mathbf{N o}$ & Opportunities & Score & Weigh & Total \\
\hline $\mathbf{1}$ & $\begin{array}{l}\text { A massive promotion of Alor tourism by the Central and } \\
\text { Local Governments }\end{array}$ & 0.263 & 0.789 \\
\hline $\mathbf{2}$ & $\begin{array}{l}\text { The interest of the outside community who wants to learn } \\
\text { about culture by visiting the Matalafang Traditional Village }\end{array}$ & 3 & 0.211 & 0.631 \\
$\mathbf{3}$ & $\begin{array}{l}\text { The development of information technology is increasingly } \\
\text { accessible, making it easier for Traditional Villages to get } \\
\text { exposure }\end{array}$ & 4 & 0.316 & 1.263 \\
\hline $\mathbf{N o}$ & Threats & Score & Weigh & Total \\
\hline $\mathbf{1}$ & $\begin{array}{l}\text { Tourism for the community is still underestimated, not many } \\
\text { have fully participated in tourism activities }\end{array}$ & 0.053 & 0.210 \\
\hline $\mathbf{2}$ & Competition with the two formerly famous traditional villages & 2 & 0.158 & 0.315 \\
\hline & TOTAL & & 1.000 & 3.210 \\
\hline
\end{tabular}

(Source: Processed research, 2020)

Table 3 is the result of EFAS processing obtained from the six key informants of this study. Data from interviews are quantified based on the results of interviews with informants. The total EFAS score obtained is 3.2105 which is in quadrant I which is strong (3.2).

\section{DISCUSSION}

Results of the SWOT Strategy Analysis The SWOT matrix provides a clear picture of the factors that are the strengths and weaknesses as well as the opportunities and threats possessed by the Matalafang Traditional Village. The SWOT matrix contains a combination of S-O (StrengthOpportunities), S-T (Strength-Threats), W$\mathrm{O}$ (Weakness-Opportunities), and E-T (Weakness-Threats). 

Village as A Cultural Tourism Destination

\section{Total Score of IFAS}

\begin{tabular}{|c|c|c|c|}
\hline \multirow[b]{2}{*}{$\begin{array}{c}4,0 \\
\text { Strong } \\
3,0-4,0\end{array}$} & $\begin{array}{l}\text { Strong } \\
3,0-4,0\end{array}$ & $\begin{array}{c}\text { Moderate } \\
2,0-3,0\end{array}$ & $\begin{array}{c}\text { Weak } \\
1,0-2,0\end{array}$ \\
\hline & $\begin{array}{l}\text { I. Growth } \\
\text { Grow and build } \\
\text { (concentration via } \\
\text { vertical integration) }\end{array}$ & $\begin{array}{l}\text { II. Growth } \\
\text { Grow and build } \\
\text { (concentration via } \\
\text { horizontal integration) }\end{array}$ & $\begin{array}{l}\text { III. Retrenchment } \\
\text { Steady and maintain } \\
\text { (circular growth) }\end{array}$ \\
\hline $\begin{array}{c}3,0 \\
\text { Moderate } \\
2,0-3,0\end{array}$ & $\begin{array}{l}\text { IV. Stability } \\
\text { Grow and build (halt } \\
\text { temporarily) }\end{array}$ & $\begin{array}{l}\text { V. Growth } \\
\text { Concentration through } \\
\text { integration horizontal } \\
\text { stability }\end{array}$ & $\begin{array}{l}\text { VI. Retrenchment } \\
\text { Harvest or divestation }\end{array}$ \\
\hline $\begin{array}{c}2,0 \\
\text { Weak } \\
1,0-2,0\end{array}$ & $\begin{array}{l}\text { VII. Growth } \\
\text { Steady and maintain } \\
\text { (diversification of } \\
\text { concentration) }\end{array}$ & $\begin{array}{l}\text { VIII. Growth } \\
\text { Harvest or divestation }\end{array}$ & $\begin{array}{l}\text { IX. Retrenchment } \\
\text { Harvest or liquidation }\end{array}$ \\
\hline
\end{tabular}

(Source: Processed research adapted from Rangkuti 2002, 2020)

Based on the tabulated data collected in table 2 for IFAS and table 3 for EFAS. The values obtained are IFAS 3.3 which is in the strong domain and EFAS 3.2 which is also in the strong domain. Based on the total value table above, the strategy for developing Matalafang Traditional Village as a cultural tourism destination is in quadrant I, which focuses on vertical integration, namely strengthening public education to consider tourism as one of the sectors that brings goodness when developed, as well as increasing product diversification therefore the Traditional Village Matalafang has a unique identity that distinguishes the two traditional villages that were well known before. In addition, Matalafang Traditional Village has high potential to grow into a destination tourism culture with pay attention to several strategic, as follows;

\section{a. Strategy for Implementing MICE- Based Activities and Making Tour Packages}

Maintaining, preserving, and enhancing local cultural traditions, Creating new ideas and work programs of the Matalafang Traditional Village Tourism Awareness Group such as culturebased MICE planning, performing cultural dances typical of the Matalfang Traditional
Village, forming art, and cultural studios to increase residents' interest in preserving culture in Alor. In addition, the government provides a stimulus for the local community by creating businesses therefore the work area becomes varied for local people, building good communication with related parties to continue to preserve the traditional 4storey house therefore it becomes a sustainable cultural attraction. Making cultural tourism packages therefore they can increase visitors, Increasing the role of local communities to continue to love and maintain the natural beauty of the surroundings therefore it remains natural to be introduced along with current technological developments and Improve human resources (HR) and still maintain the attitude of community harmony.

\section{b. Strategy for Procurement of Training for Tourism Human Resources and Repair of Infrastructure in Matalafang Traditional Village}

Improving the quality of human resources (HR) by conducting socialization and tourism awareness training that leads to the development of tourist objects, business opportunities, and improving the community's economy. Adding and improving facilities to support tourism 
activities and creating jobs for the community. Improving access roads so as to make it easier for the community to carry out tourism activities, increase human resources, and utilize technology and information to introduce the tourism potential they have.

\section{c. Strategies to Maintain Tradition through Preservation of Traditional Dance and Ritual Culture to the Young Generation of Matalafang Traditional Village}

Keep maintaining and maintaining traditions and culture so as not to be displaced by the entry of foreign cultures, Preserving and maintaining the authenticity of traditions and culture in increasing tourist visits, Loving and preserving nature in order to remain sustainable, and Using cultural strength as a unifying nation.

d. Strategies to Encourage Innovation and Creativity of Traditional Village Communities

Increase and strengthen Increase human resources (HR) in order to continue to love and preserve local culture, Increase human resources (HR) to generate new ideas in creating creativity so as to improve the community's economy

\section{CONCLUSION}

Based on the results of the research on the development strategy of the Matalafang Traditional Village as a cultural destination, the following conclusions can be drawn;

1. The potential for cultural tourism in the Matalafang Alor Traditional Village consists of various types, namely traditional dances, traditional houses, traditional ceremonies and rituals, local languages, religious systems, and various traditional tools found during this research. This cultural wealth is a strong asset for the Matalafang Traditional Village to become a culture-based tourist destination.
2. Even though it has diverse cultural tourism potentials, the Matalafang Traditional Village requires intervention from various parties, especially in relation to increasing education and participation of local human resources. This is because based on field findings $\mathrm{HR}$ is the main obstacle therefore there needs to be special attention from the government in improving human resources (HR). The aim is to create a community capable of developing attractive tourist destinations to visit. In addition, improvement of infrastructure is also one of the things that can increase the success of the development of the Matalafang Traditional Village as a cultural destination.

Recommendations for the development of this research include; The government, especially the Tourism Office, needs to increase promotion in addition to relying on tour guides who take tourists to tourist destinations. Increasing community involvement in communitybased tourism development with tourism awareness education to make Matalafang Traditional Village ready and independent as a cultural tourism destination.

\section{REFERENCES}

Anggayana, I. A., Suparwa, I. N., Dhanawaty, N. M., \& Budasi, I. G. (2020). Lipang, Langkuru, Waisika Language Kinship: Lexicostatistics Study in Alor Island. International Journal of Psychosocial Rehabilitation, 24(4), 301-319.

A.J, Mulyadi. 2012. Kepariwisataan dan Perjalanan, Jakarta: Raja Grafindo Persada.

Alelang, I. F., Hakim, L., \& Batoro, J. (2018). The Ethnobotany of Abui's Home Gardens and its Potentiality to Support Rural Tourism Development in Alor, Indonesia. Journal of Indonesian Tourism and Development Studies, 6(2), 120-125. 
Arjana, I Gusti Bagus. (2016). Geografi Pariwisata dan Ekonomi Kreatif. Jakarta: Rajawali

Asa, M. I., \& Santosa, A. B. (2020). THE LEARNING MANAGEMENT OF CREATIVE PRODUCT AND ENTREPRENEURSHIP IN VOCATIONAL HIGH SCHOOL IN FRONTIER, OUTERMOST AND LEAST DEVELOPED REGIONS IN ALOR REGENCY, EAST NUSA TENGGARA PROVINCE. LEARNING, 3(01).

Jovicic, D. (2016). Cultural tourism in the context of relations between mass and alternative tourism. Current Issues in Tourism, 19(6), 605-612.

Darsiharjo, D. (2016). Konsep Penataan Ruang Situ Bagendit Sebagai Kawasan Wisata Alam dengan Fungsi Lindung di Kabupaten Garut. Jurnal Manajemen Resort dan Leisure, 13(1).

Koentjaraningrat. (2004)b. Kebudayaan Mentalitas dan Pembangunan. Jakarta: Gramedia Pustaka Utama

Kotler, P. (2002). Manajemen Pemasaran,Edisi Milenium. (2002). Jakarta: PT.Prehalindo

Kusi, J., \& Rero, D. (2020). KAMPUNG ADAT WOLOTOPO SEBAGAI DESTINASI PARIWISATA KABUPATEN ENDE FLORES. Historis: Jurnal Kajian, Penelitian dan Pengembangan Pendidikan Sejarah, 5(2), 151-159.

Muawanah, U., Triyanti, R., \& Soejarwo, P. A. (2020). Dampak Ekonomi Wisata Bahari Di Kabupaten Alor.
Jurnal Sosial Ekonomi Kelautan dan Perikanan, 15(1), 33-46.

Nafila, O. (2013). Peran Komuninas Kreatif dalam Pengembangan Pariwisata Budaya di Situs Megalithikum Gunung Padang. Jurnal Perencanaan Wilayah dan Kota, 24(1).

Osin, R. F., Kusuma, I. R. W., \& Suryawati, D. A. (2019). Strategi Pengembangan Objek Wisata Kampung Tradisional Bena Kabupaten Ngada-Flores Nusa Tenggara Timur (NTT). Jurnal Ekonomi dan Pariwisata, 14(1).

Rangkuti, Freddy. (2002). Analisis SWOT Teknik Membedah Kasus Bisnis. Jakarta: PT Gramedia Pustaka UtamaSugiyono. 2015. Metode Penelitian Pendidikan (Pendekatan Kuantitatif, Kualitatif dan R\&D). Penerbit CV. Alfabeta: Bandung.

Suwena, I Ketut dan Widyatmaja I.G.N, (2010). Pengetahuan Dasar Ilmu Pariwisata. Bali: Udayana University Perss.

Tjahjono, A., Komalasari, Y., \& Maulana, A. (2019). Evaluation Of Parking Facilities For Delivery Vehicle/PickUp At The Ferry Port Of Kalabahi, Alor District, East Nusa Tenggara Province. IWTJ: International Water Transport Journal, 1(1), 12-26.

Tokan, M. K. (2015). Characteristics of The Outermost Small Islands In East Nusa Tenggara Province Indonesia. International Journal of Oceans and Oceanography, $\quad 9(1), \quad 23-$ 42.https://www.disbudpar-alor.com 